\title{
Legal Regulation of the Subsoil Use in Arctic Region
}

\begin{abstract}
Rashad A. Kurbanov
Doctor of Law, Professor, Honored Lawyer of the Russian Federation, Head of the Secretariat of the Delegation of the Russian Federation at the European Commission for Democracy through Law (Venice Commission) at the Institute of Legislation and Comparative Law under the Government of the Russian Federation, Head of the Civil Law and Procedure Department at the Russian University of Economics named after G.V. Plekhanov Email: mos-ssp@mail.ru
\end{abstract}

\section{Doi:10.5901/mjss.2015.v6n3s1p63}

\section{Abstract}

Recently interest in Arctic areas show not only the eight Arctic countries. Its presence in the Arctic claim other countries in Europe, Asia, America, even those that are geographically located in a different hemisphere and are very difficult to call circumpolar. For example, the readiness to develop fields in the Arctic shelf areas declared Germany, Japan, India, South Korea, China, Brazil and about 20 more countries. Moreover, China, India, Singapore and some other countries are already developing strategies to use Arctic Northern Sea route. It is necessary note that at the constitutional level all Arctic countries in different ways (both directly and indirectly) regulate issues related to the Arctic. In particular, the provisions on the rights of indigenous peoples take place in most constitutions and are equally applicable to the Arctic region, as the number of indigenous peoples of the Arctic is about 400 thousand people. Besides that at the national level in each of the Arctic countries are the main program "Arctic Documents "and special" Arctic "legislation (except Finland and Sweden). In this study we considerate the main basic program documents and legal regulations governing this sector in Russia.

Keywords: Arctic region, Russian Federation, natural resources, international law, Northern Seaway Route, Arctic territories, Constitution Russian Federation, production sharing agreements, Federal Government of Russian Federation

\section{Introduction}

The Arctic region is currently one of the poorly developed regions of the world. At the same time the development of this region is very promising.

At present many countries are interested to develop of the Arctic including the Russian Federation.

It is logical that all spheres of social relations regulated by law. And in the context of the Arctic region are affected a greater degree of relationship between the states regulated by international treaties. However, national legislation directly effects on the implementation of international agreements.

Russia is the largest Arctic states, so the study of the Russian legislation relating to the Arctic region is undoubtedly important. The aim of the present study is to analyze the development of the Russian legislation aimed at regulating activities in the Arctic region.

\subsection{Literature review and methods}

Issues of legal regulation of relations in the Arctic region at different times were devoted to the work of authors such as T. Khabrieva (Russian Arctic - Territory of Law (2014)), V. Avhadeev (International legal regulation of the consequences of the industrial exploitation of the resources of the continental shelf in the Arctic (2013)), A. Zagorski (Arctic: space cooperation and common security (2010)), N. Loukacheva (Polar Law Textbook (2010)), N. Bankes (Land Claim Agreements in Arctic Canada in Light of International Human Rights Norms (2009)) and others.

To achieve this goal have been used and the general scientific specific scientific methods: formal-legal method, legal methods of modeling and forecasting. Also, the study used dialectical, historical, logical, comparative method and system-structural analysis.

\section{History and Definitions}

The Resolution of the Presidium of the Central Executive Committee of the USSR from 15 April 1926 "About the 
declaration of the lands and islands located in Ocean as a territory of the USSR" defined the territory of Russia in Arctic region as «...discovered and can be discovered in future lands and islands, which are not included to the territory, recognized by the government of the USSR as a territory of other foreign states, located in Arctic Ocean to the north of the USSR coast till North pole between the meridian $32^{\circ} 4^{\prime} 35^{\prime \prime}$ east from Greenwich, passing along the eastern side of Vaida-mouth through triangulation mark on Cape Kekurskom, and the meridian 168 ${ }^{\circ} 9^{\prime} 30^{\prime \prime}$ west longitude from Greenwich, passing the middle of the strait, which is separating the islands of Krusenstern and Ratmanov of Diomede Islands in the Bering Strait».

By the Cornerstones of State Policy of Russian Federation in Arctic for the period till 2020 year and forcoming perspective, the Arctic zone of Russia defined in accordance with the item 1 of the Cornerstones as the zone which includes wholly or partially the territories of the Republic of Sakha (Yakutiya), Murmansk and Arkhangelsk regions, Krasnoyarsk territory, Nenets, Yamalo-Nenets and Chukotka autonomous districts, which are defined by the Decision of the State Commission for Arctic region under the Council of Ministries of the USSR from 22 April 1989, as well as lands and islands indicated in The Resolution of the Presidium of the Central Executive Committee of the USSR from 15 April 1926 "About the declaration of the lands and islands located in Arctic Ocean as a territory of the USSR", and territorial seas, exclusive economic zone and the continental shelf of Russian Federation, where Russia enjoys sovereign rights and jurisdiction according to international law.

\section{Base of Natural Resources and Potential Deterrents for Development}

Natural resources are one of the main factors, which defines the development of legal regulation of its use. The main Arctic's natural resources are hydrocarbons.

The base of natural resources potential are hydrocarbons, which are up to $25 \%$ of the world's resources. Special geographical situation of Arctic region defines it's special geopolitical importance. Through the Russian territory in Arctic passes the shortest transit ways between EC, Japan, China, USA and Canada.

Although the mining activities on the continental shelf are slowed down by:

- the absence of technical and technological possibilities for research on the sea-fields and for extraction activities in the harsh conditions of Arctic region;

- the low amount of Russian investment activity to the research and extraction of the sea-fields on basis of the high risk of such works and need of big amount of the investments;

- lack of proper regulation by international law instruments, among them indefinite outer edge of the continental shelf of Russia in Arctic region (it is necessary to present to the Commission on the Limits of the Continental Shelf (CLCS), established in accordance with the UNCLOS Convention, additional geological, geophysical and hydrographic data for reasoning outer edge of the continental shelf of Russia in Arctic and to make necessary negotiations with Arctic states) ${ }^{1}$;

- bad science scrutiny of the Russian Arctic shelf in contrast with the Arctic shelf of other Arctic states (from the early 70-th of the past century in the western part of Russian Arctic and Okhotsky Sea the seismic exploration was made with an average density of 0.24 line $\mathrm{km}$ by $1 \mathrm{~km}^{2}$, at the same time the density of seismic survey made for example in Northern Sea is more than 4 line $\mathrm{km}$ to $11 \mathrm{~km}^{2}$ ).

Due to the fact the transport activity increasing and to the fact that continental shelf becomes the principal area of the subsoil use - the Arctic region becomes significant as a transport system - Northern Seaway Route historical national transport system of Russian Federation in Arctic, uniting such subsystems as European North, Siberia and Far East².

At the same time the absence and high level of deterioration of infrastructure cannot afford to provide:

- the security of Northern Seaway Route, cross-polar flights by the reasons of critical deterioration of navigational equipment and technological impossibilities of data exchange between vessels, aircrafts and polar stations (at the present time Russia doesn`t dispose by the equipment able to maintain a reliable communication above $68^{\circ}$ northern latitude);

- the control under illegal activity (illegal fishery, abuse and breach of the technological and technical regulations

\footnotetext{
1 In the western part of Russian Arctic sea areas are not delimitated with Norway in Barentz sea. In the eastern part of Russian Arctic sea areas are not delimitated with USA (the bilateral treaty between USSR and USA from 1 June 1990 is not ratified by Russian Federation).

2 While estimated using of the North Sea Way Route the seaway from for example the Dutch port Rotterdam reduces: to Yokohama (Japan) - for 3860 sea miles (34\%), to Shanghai - or 2449 sea miles (23\%), to Vancouver - for 1932 sea miles (22\%). / Pazovskij V.M. The Northern Sea Way Route: the appraisals of foreign specialists. // Eco. 2001, N8. - P. 2-12 
and mining licenses in the given area etc.);

- the ice patrol activity (Russia depends totally on the information, received from foreign satellites, the speed of decoding of such a data is extremely low);

- the monitoring, prevention and notification of natural and technological situations;

- the monitoring and pollution of the environment.

The increasing of the extraction, processing and transportation of mineral resources can be accompanied by the appearance of the new sources of the environmental pollution in Arctic, which are very dangerous in the territory of the continental shelf.

Arctic is a climate forming region of the planet, so the climate change in Arctic should change it all over the world. Important problems of global warming for Arctic are the extremely high level of morbidity rate and premature mortality (especially among the indigenous inhabitants) etc.

\section{Basic Elements of the Legal Regime}

It is possible to distinguish such elements of legal regime of the subsoil use of Russian Arctic region as: 1) legal regulation of the environment protection, including the protection of the indigenous population of the Far North; 2) legal regulation of the mining activity: research, exploration and extraction of the mineral resources; 3 ) legal regulation of the transportation by the Northern Seaway Route for seismic survey and for the extraction of mineral resources.

The legal statute of the Russian Arctic territories defines primarily by the Constitution of Russian Federation ${ }^{3}$, which defines "territory of Russian Federation" as land, internal waters and territorial sea of Russia (62 (1) of the Constitution of Russian Federation). According to the part 2 of the same article of the Constitution Russian Federation has a jurisdiction under its continental shelf and exclusive economic zone.

There is no universal international treaty, dedicated to the Arctic, so the only legal source, which impacts the continental shelf and exclusive economic zone of Russia in Arctic, is UN Convention on the Law of the Sea of 1982 (UNCLOS) ${ }^{4}$. The only multilateral treaty, which affects the legal statute of the territories, located in Arctic, is Spitzbergen Treaty of 9 February $1920^{5}$ with 40 states participated in. However only Norway and Russia executes the economically significant activity (coal mining) in the Spitzbergen archipelago .

In accordance with the art. 3 of this Treaty Parties can expand the scientific research and to restart the geological and geophysical survey to activate fishery and tourism activity.

Among bilateral treaties the special role belongs to the treaties on the delimitation of the continental shelf.

The Treaty between USSR and Norway on the sea border between two countries was signed and ratified on 15 February $1957^{6}$. As for the delimitation of the continental shelf between both states, the negotiations are performed for at least 40 years.

\subsection{Program documents}

Although the program documents are not sensu stricto ${ }^{7}$ the sources of law, it will not correct to ignore them. The program documents define the development of the legal regulation in the most (from the authority's point of view) actual scopes.

The Conception of the long-term socio-economic development of Russian Federation for period till 2020, approved by the Decision of the Government of Russian Federation from 17 November 2008 N1662-p ${ }^{8}$, assign a mission to increase the effectiveness of natural resources use, the effectiveness of the Northern Seaway Route exploitation, the decrease of the impact to the environment, the adaptation of the infrastructure to the climate change, development of the information technologies etc.

Sea Doctrine of Russian Federation for the period till $2020^{9}$ defined as a basis of national sea policy in Arctic

\footnotetext{
${ }^{3}$ Rossijskaya gazeta, N7, 21.01.2009.

${ }^{4}$ Done at Montego-Bay (Jamaica) 10 December 1982, ratified by the Federal law of 26 February 1997 N30-FZ «On the ratification of the United Nations Convention of the Law of the Sea and a Treaty for executing the part XI of the United Nations Convention of the Law of the Sea " // CL of RF 03.03.1997, N9, art. 1013.

${ }^{5}$ Collection of existing treaties, agreements and conventions, concluded between USSR and foreign countries. - Moscow, 1938. - P. 53

$-61$.

${ }^{6}$ Vedomosti VS USSR. 5 July 1957, N14. St. 344.

7 In strict meaning, literally (lat.).

${ }^{8}$ CL of RF 24.11.2008, N47, Art. 5489.

${ }^{9}$ Approved by the President of Russian Federation on 27 July 2001.
} 
region - the creation and maintenance of the conditions for Russian float activity in Barenz, Beloye and other Arctic Seas on the Northern Sea Way Route. This Doctrine has marked such long term-tasks as research and development of Arctic region with orientation to export and international trade, solving the social problems of Arctic inhabitants; the defense of national interests of Russian Federation in Arctic region; consider of defense interests of the state during the exploration and exploitation of biological and mineral resources in the exclusive economic zone and the continental shelf of Russia; the limitation of the foreign military activity in Arctic on the basis of bilateral treaties with world's sea powers; the support of the national interests of Russian Federation in the North Sea Way Route and it's state regulation, icebreaking service and equal access for all carriers interested in (including foreign carriers).

In September 2008 the Cornerstones of State Policy of Russian Federation in Arctic for the period till 2020 year and forcoming perspective were approved the President of Russian Federation. They contained the main problems of Arctic region, national interests of Russian Federation, the tasks of state policy and measures of its realization. Part VI of the Cornerstones, including only one item, has defined the main stages of its realization.

First stage (2008 - 2010) -provided the geological, geophysical survey and other works on the continental shelf to prove the external borders of Russian Arctic zone;

Second stage (2011 - 2015) - legal confirmation of the boarders of Russian Arctic zone on the bases of the above mentioned geological, geophysical survey. This will help to realize the priorities of Russia and to realize it's advantages on the extraction and transportation of the energy resources; structure economy reform in Arctic zone of Russian Federation; construction and development of the North Sea Way Route for transit; the united information space of the Arctic zone of Russian Federation.

Third stage (2016 - 2020) - Russia`s Arctic zone will become a strategic resources base of Russian Federation.

\subsection{Russian law regulation of Arctic region}

Russian law regulation of Arctic region is not unified in present. The legal regulations is performing obiter dictum ${ }^{10}$ by the different sources of law of different levels.

Law of Russian Federation from 21 February 1992 N2395-1 "About the Subsoil"11 stipulates the common legal conditions of mining in the territory of Russia, and it's continental shelf, including the Arctic area. In accordance with Art. 1(2) of this law, the norms of the Federal laws "About the Continental Shelf' and "About the Exclusive economic zone" enjoys priority over the common provisions of the Russian Law "About the Subsoil". This Law doesn't contain any special provisions, which can be applicable to the mining in Arctic. Except the Art. 22.1 "Right to acquisition, storage and use of service weapon by the persons executing field-works of regional geological survey, exploration in the districts of Far North and the locations, which are legally recognized as similar to it".

In 2008 the Federal Law from 29 April 2008 N58-FZ "About the changes to some legal acts of Russian Federation and about the loss of power of some of legal provisions by the approval of the Federal law "About the procedure of the foreign investments in corporations which are strategic for national defense and security"12 has introduced special rules for mining for subsoil parcels of federal level, which checklist is officially published by Federal Mining Agency in "Rossijskaya gazeta" In 2011 the legal definition of the "local mining parcel" was clarified to stop the practice, when regional authorities declared the mineral parcels, which contained oil and gas, as "local" to simplify its transition to future mining users.

Federal Law from 30 December 1995 N225-FZ "About the production sharing agreements"13 stipulates the mining on the conditions of the production sharing in Russian Federation. In distinction from the Law "About the Subsoil" it contains special rules, which although not directly apply to the subsoil use in arctic, but are in any case applicable to.

To include the subsoil parcels to the list of parcels, which are intended for production sharing agreements and located in the territory of the residence and economic activity of the indigenous nations, it is necessary to obtain the decision of the regional legislature, which should be taken in considering with the decision of the indigenous population and the with the decision of the local self-governance authorities.

Art. 2 item 1 (4) of the same law determines the inclusion of the mining parcel in these checklist by the "impossibility of the geological survey and extraction of mineral resources on the conditions of the mining license as it is provided in the Law "About the Subsoil".

\footnotetext{
10 Said in passing (lat.).

${ }^{11} \mathrm{CL}$ of RF 06.03.1995, N10, art. 823.

${ }^{12} \mathrm{CL}$ of RF $05.05 .2008, \mathrm{~N} 18$, art. 1941.

${ }^{13} \mathrm{CL}$ of RF 01.01.1996, N1, art. 18.
} 
Item 6 of article 4 of the Federal law "About the production sharing agreements" contains additional conditions, defined finally by the federal government:

1) the mining activity of the subsoil parcel can protect working places for so-called "city-forming organizations" and it's termination will definitely result to negative social effect ${ }^{14}$;

2) the mining activity of the subsoil parcel is performed on the continental shelf of Russia and Far North and locations, officially equivalent to Far North, without inhabited territory, transport and other infrastructure;

3) the mining activity of the subsoil parcel requires special high-cost technologies for the extraction of the mineral resource in the harsh geological conditions.

Formally, this article means exactly combination of these conditions, which narrows down the scope of the article 4 of the above mentioned act in rem ${ }^{15}$.

The commission for working out the mining conditions includes the representatives of the Ministry for Regional Development of Russian Federation (which is at the present time the state body, responsible for indigenous people protection ${ }^{16}$ and the representative of the local self-governance authorities).

Production sharing agreements for subsoil parcels on the continental shelf or in the exclusive economic zone of Russia (the great majority of Russian mineral resources in Arctic are located in these territories) are approved by the special federal laws, while other production sharing agreements are approved on the basis of Federal laws (item 5 art 6 (2)).

In accordance with art 7 (3) of the Federal law "About the production sharing agreements" the investor is obliged to take measures for the indigenous people protection, and to pay compensations in the cases and in the order imposed by the federal Government.

Federal Law "About the internal sea waters, territorial sea and contiguous zone of Russian Federation" from 31 July $1998 \mathrm{~N} 155-\mathrm{FZ}^{17}$ approved and concretized the constitutional provision under which the internal sea waters and territorial sea are (unlike the exclusive economic zone and continental shelf of Russia) the territory of Russian Federation. Under Article 16 (4-7) of this act the construction \& use of the artificial installations and constructions and pipelines, drilling etc. in the internal sea waters, territorial sea of Russia are exercised in accordance with Russian water laws ${ }^{18}$ and in the order, imposed by the federal Government.

While exercising the mining activities in the internal sea waters and the territorial sea of Russia the mining license automatically gives to the licensee the power to construct and use of the artificial islands, structures and pipelines, drilling works in accordance with subsoil and urban construction laws.

The Federal Law "About the continental shelf of Russian Federation" has a priority over the Law "About the Subsoil", which applicable to the relations on the continental shelf only if the special law "keeps silence".

Under the Federal law "About the continental shelf of Russian Federation" Russia has exclusive rights for mining activity in the continental shelf (if Russia doesn't perform the mining activity in the continental shelf, other persons are obliged to obtain the Russia`s approval).

The exclusive right of Russia to permit the drilling works in its continental shelf and to permit and regulate the installation of the artificial islands and constructions on the continental shelf has another legal nature. In this case the common definition of "exclusivity" of the rights as "...impossibility for other persons to have this right and to exercise them"19.

Russia also executes jurisdiction over the pipelines constriction and exploitation protection and safety on the territory of the continental shelf.

\section{North Sea Way}

Mining activities in Arctic are impossible without using the North Sea Way Route. The majority (approximately 97\%) of goods carried by this transport way are extracted mineral resources or a fuel. The absence of piracy and short distance in contrast with its main concurrent - the Suez channel and the Strait of Malacca makes this transport artery very

${ }^{14} \mathrm{Almost}$ all cities over the Arctic circle in the territory of Russia are so-called "single-industry towns".

15 Power about or against "the thing" (lat.).

${ }^{16}$ The Regulation of the Government of Russian Federation from 28 September 2004 N501 "About the powers of the Ministry of the Regional Development of Russian Federation"// CL of RF 04.10.2004, N 40, art. 3956).

${ }_{17} \mathrm{CL}$ of RF 03.08.1998, N31, art. 3833.

${ }^{18}$ In accordance with Art 2 (1) of Water Code of Russia includes the Water Code itself with the provisions of other federal laws and the provisions of the regional laws.

${ }^{19}$ Naletov K.I. Once more on the nature of the concession agreement // Pravo i politica. 2005. N3. - P. 20. 
perspective. Also the district of North Sea Way Route is of interest for mining itself. The adjacent districts contains $35 \%$ of the world`s oil and gas supplies ${ }^{20}$.

The non-development of the infrastructure of the North Seaway Route is its global problem. And the absence of legal basis puts an end to its advantages.

In 1932 the Main Department of the North Seaway Route (Glavsevmorput') was established, and in 1971 by the Decision of the Council of Ministers of the USSR form 16 September 1971 N683 was established the North Seaway Route Administration under the Sea transport Ministry of the USSR (at the present time it is the Department of Icebreaking providing and hydrography of the Federal Sea and River Transport Service of Russian Federation).

In summer of 2006 for the first time after 20 years break the transit through the North Seaway Route from Murmansk to Petropavlovsk-Kamchatskij was carried out. In 2010 this figure was increased to 4 transits and 111 thousand tons of goods were carried out. In 2011 - more than 800 tons of goods was carried out, though the average potential is approximately 8 million tons a year.

At present time the North Seaway Route uses on the basis of the Federal law "About the internal sea waters, territorial sea and contiguous zone of Russian Federation"21 (Art. 14 of this law).

On 14 of September 1990 the Ministry of Sea Fleet of the USSR has approved the Regulations for navigation on the seaways of the northern sea route22.

In accordance with 1.4 these Regulations the term «vessel» includes any ship or other craft, including the oil platform. According to item 2 of these Regulations the navigation through the Northern Sea Route have to be organized on the basis of non-discrimination for vessels of all States.

The navigation through the Northern Sea Route exercises in the following order: The Owner or Master of a vessel, intending to navigate through the Northern Sea Route, shall submit to the Administration (Marine Operations Headquarters) a notification and a request for guiding through the Northern Sea Route in compliance with form and deadlines, indicated on the Rules ${ }^{23}$, and shall guarantee the payment for the icebreakers assistance and the confirmation of the payment (guarantee of payment icebreaker's charge IM 6451/96, ZH 1954/7/96) (item 3.1. of the Regulations).

The Administration (Marine Operations Headquarters) shall consider a request and inform a sender of the possibility of guiding through the Route and other circumstances to be taken into consideration by the Owner or Master.

A vessel, intending to navigate the Northern Sea Route, shall satisfy special requirements ${ }^{24}$ and its Master or a person, replacing him, shall be experienced in operating a vessel in ice. In case where these persons have no such experience, or when Master requests so, the Administration (Marine Operations Headquarters) may assign a State Pilot to the vessel to assist in guiding it through the Northern Sea Route. The icebreaker wiring exercises by the FGUP "Atomflot" in accordance with the point 7.4 of the Regulations. The mandatory icebreaker guiding of vessels with ice pilot on board is necessary for the Strait of Vil'kitskogo, the Strait of Shokal'skogo, the Strait of Dmitriya Lapteva and the Strait of Sannikova due to unfavorable navigational situation and ice conditions and for the purpose of ensuring safe navigation.

The Order of Federal Rates Service from 7 June 2011 N122-t/1 "About setting of rates for services of the icebreaker fleet on the Northern Sea Route"25 determines maximum rates on ice-breaker fleet services along the NSR routes. Tariff defines on the basis of the unity of the goods and depends firstly from the type of cargo and secondly from the district of the icebreaker wiring.

Besides, it should not be permitted to navigate the Northern Sea route to vessels, which have not aboard a certificate of due financial security with respect to the civil liability of the Owner for damage inflicted by polluting marine

\footnotetext{
${ }^{20}$ Kurbanov R.A. Foreign investment and fuel-energy complex: issues of public- legal and international -legal regulation in the countries of the Commonwealth of the Independent States. The monograph is in two parts. Managing Editor Kurbanov R.A. Publisher RGTEU. M. 2011.

${ }_{21} \mathrm{CL}$ of RF 03.08.1998, N31, art. 3833.

${ }_{22}$ Published 13 July 1991 in «Izvesheniya Moreplavatelyam», N29.

${ }^{23}$ This document has to contain the following data: 1. Name of ship, IMO number, flag, port of registry, shipowner (full name and full address). 2. Gross/net tonnage reg.t. 2.1. Full displacement of the ship. 3. Main dimensions (length, breadth, draft), output of main engines, propeller (construction, material), speed, year of build. 4. Ice class and classification society, date of last examination. 4.1. Construction of bow (ice knife or bulb-bow). 5. Expected time of sailing through the NSR. 6. Presence of certificate of insurance or other financial security in respect of civil liability for environmental pollution damaged. 7. Aim of sailing (commercial voyage, tourism, scientifi research, etc). 8. List of deviations from the "Requirements to the Design, Equipment and Supply of Vessels Navigating the NSR".

${ }^{24}$ This criteria means the vessels of gross tonnage 300 tons and more. The possibility of navigation of vessels with smaller tonnage is the subject of special permission (item 2.1. Requirements for the design, equipment and supplies of vessels navigating the northern sea route).

${ }^{25}$ Published in Rossijskaya gazeta, N138, 29.06.2011.
} 
environment and the northern coast of the USSR. The purification of ice is technologically more compound than the soil or even water purification. The inspection of the vessel to verify compliance with the present Requirements is performed at the expense of the owner of the vessel and can be carried out in the ports of Murmansk, Nakhodka, Vladivostok or Provideniya, as well as in any other port, convenient to the owner of the vessel (point 2.11 Requirements for the design, equipment and supplies of vessels navigating the northern sea route).

According to the point 7.1 of the mentioned Regulation, the navigation of vessels through the seaways of the Northern Sea Route shall be performed during the navigational period, the beginning and the end of which shall be determined by the Administration and Marine Operations Headquarters in consideration of forecasted and the actual state of ice, navigational, hydrographic weather. and other conditions. The main natural problem of the Northern Sea Route is a short period of navigation, although by the matters of global warming and due to the fact that Russia has a strong icebreaking fleet, this problem can be solved ${ }^{26}$.

In accordance with the Decision of the Council of Ministers of the USSR N683 form 16 September 1971 "About the Administration of the Northern Sea Route"27 and Regulations for Navigation on the Seaways of the Northern Sea Route (rule 1. par. 1.5 and rule 4) the requirements for the design, equipment and supplies of vessels navigating the Northern Sea Way Route were approved.

The mentioned requirements are intended to ensure safety of navigation and to prevent pollution of the marine environment and northern coast of Russia, which is especially vulnerable area, where it is prohibited to dispose of any amount of oil products and other harmful substances and their mixtures containing such substances in amounts that exceed the established standards in accordance with the legislation.

For improvement of law regulation of the North Sea Way Route the Government of Russia has `submitted the Federal Law N132-FZ dated 28.07.2012 "About the amendment to some laws of Russian Federation in the scope of the state regulation of the merchant marine in the North Sea Way Route area". It contains a new definition of the North Sea Way Route, outlines the powers of the Federal Government of Russian Federation for delineation of the North Sea Way Route, provides the new charge for the security of navigation, which defines in accordance to the Russian antimonopoly law, the charge for icebreaker and ice wiring service in the North Sea Way Route, which is a state monopoly, according to this draft law provisions.

At the present time the North Sea Way Route is not in use as a transit way by the foreign vessels.

One of the principal problem of the North Sea Way Route is it's incapacity for the transshipment. In 2015 it is planning to begin the construction of the Murmansk transport hub.

\section{References}

Collection of existing treaties, agreements and conventions, concluded between USSR and foreign countries. - Moscow, 1938

Khabrieva T. Russian Arctic - Territory of Law. - Moscow, 2014

Kurbanov R.A. Foreign investment and fuel-energy complex: issues of public- legal and international -legal regulation in the countries of the Commonwealth of the Independent States. The monograph is in two parts. Managing Editor Kurbanov R.A. Publisher RGTEU. M. 2011.

Natalia Loukacheva. Polar Law Textbook. - Nordic Council of Ministers, Copenhagen 2010.

Nigel Bankes, "Land Claim Agreements in Arctic Canada in Light of International Human Rights Norms," in Yearbook of Polar Law, Martinus Nijhoff Publishers, vol. 1 (2009), pp. 175-232.

Pazovskij V.M. The Northern Sea Way Route: the appraisals of foreign specialists. // Eco. 2001, N8. - P. 2-12

26 Though in the perspective other problem can become actual - the problem of the obsolescence of the Russia's icebreaking float. As the vice-president of the Russian Academy of Sciences Nikolai Leverov appraises, Russia's icebreaking float can become incapable to the year 2020 without renewal.

${ }^{27}$ CD or USSR, 1971, N07, art. 124. 